\title{
Does accessible technology need an 'entrepreneurial state'? The creation of an EU market of universally designed and assistive technology through state aid
}

\author{
Delia Ferri* \\ Department of Law, Maynooth University, Maynooth, Ireland \\ (Received 28 February 2015; accepted 30 May 2015)
}

\begin{abstract}
EU State aid law has sought to enable people with disabilities to obtain employment, yet has not been explicitly included in the toolbox of policy options to improve the availability and choice of accessible technology within the EU Internal market. This seems to be the consequence of an inherent bias against State intervention in the market, which is mostly unwelcome since it can limit open and free competition. This also reiterates the 'less-aid' policy and the purely economic approach to State aid professed by the European Commission. Against this background, this article discusses the potential for EU State aid policy to foster both 'design for all' and innovative assistive devices for people with disabilities. It seeks to argue that the goal of an EU-wide market of accessible technology can be achieved using EU State aid law. In particular, this article aims to highlight that a more targeted use of EU State aid law can lead developers to increase the production of accessible goods, to adjust or reduce prices and to provide consumers with a greater degree of choice in a greater number of marketplaces. Whilst it adopts a legal approach, this analysis relies inter alia on economic evidence and recalls the pamphlet recently published by Mazzuccato, from which the title of this work has drawn inspiration.
\end{abstract}

Keywords: EU state aid law; accessible technology; design for all; assistive technology; $\mathrm{R} \& \mathrm{D}$

\section{Introduction}

In recent years, the European Union (the EU) has strongly advocated for the removal of barriers that prevent individuals with disabilities from achieving equality of opportunity and full participation in all aspects of life and has attempted to mainstream disability in different areas under its competence ${ }^{1}$ (Waddington 2006, 2009, 2011a; Mabbett 2005; Ferri 2014). The conclusion of the UN Convention on the Rights of Persons with Disabilities (hereinafter 'the Convention' or the 'UNCRPD') ${ }^{2}$ has unequivocally supported this mainstreaming process and has pushed the EU's action aimed at promoting active participation of persons with disabilities in society.

In compliance with the UNCRPD, the European Disability Strategy 2010-2020 (the 'EDS 2010-2020' or the 'Strategy'), ' adopted by the European Commission (hereinafter simply the 'Commission') in November 2010, sets forth an ambitious policy framework to achieve full equality of people with disabilities in Europe (Hosking 2013). It is centred on eight interconnected thematic areas that affect (or coincide with) different EU 
competences (exclusive, shared or supporting): ${ }^{4}$ accessibility, participation, equality, employment, education and training, social protection, health and external action. Among these thematic areas, the Strategy marks a strong pivot in accessibility (Charitakis 2013), reflecting the importance granted to the principle of accessibility by the UNCRPD (see Ferri, Giannoumis, and O'Sullivan 2015, Halvorsen 2009). Drawing inspiration from Article 9 UNCRPD, the EDS 2010-2020 defines accessibility as granting people with disabilities full access to the physical environment, transportation, information and communications technologies and systems (ICT), and other facilities and services, and conceives it as a 'precondition for participation in society and in the economy'. This broad definition encompasses the variety of barriers that people with disabilities experience in accessing their physical environment and participating in the market as consumers.

The Strategy acknowledges the vital role that assistive devices play in allowing persons with disabilities to access certain goods and services and singles out, among the main goals to achieve and enhance accessibility, the promotion of an EU-wide market of assistive technology (AT). ${ }^{5}$ The EDS 2010-2020 does not define AT; however, it seems safe to infer a broad conceptualization of AT in line with International Standardization Organization (ISO) and International Electrotechnical Committee (IEC) Guide 71. These guidelines for standards developers address the needs of older persons and persons with disabilities (Ferri, Giannoumis, and O'Sullivan 2015), and are in line with the definition adopted by scholars of different disciplines (ex pluribus Abbott 2007; Scherer et al. 2007; Borg, Larsson, and Östergren 2011; Ravenberg 2012; Abbott et al. 2014; Gramstad, Storli, and Hamran 2014). This broad definition would allow the Commission and, more generally, the EU legislature to include any type of assistive, adaptive and rehabilitative devices aimed at compensating for functional limitations, i.e. any kind of equipment, ranging from low-tech walking devices to high tech assistive Information and Communication Technology (ICT), including Ambient Assisted Living (AAL) solutions. ${ }^{6}$ Beside the improvement of AT's availability and choice, the Strategy clearly affirms the EU's commitment to enhance 'Design for All' or, as it is also referred, 'Universal Design' (UD). ${ }^{7}$

In order to expand the bulk of accessible goods (both universally designed products and $\mathrm{AT})^{8}$ manufactured and marketed in the EU, the Strategy has emphasized 'demand side' solutions, focused on the enactment of new legislation and the enhancing of standardization. ${ }^{9}$ In more general terms, the Commission aims to increase the demand of accessible goods by imposing accessibility obligations, or by facilitating the development of common standards or accessibility requirements.

In the EDS 2010-2020, rather surprisingly State aid is not mentioned expressis verbis. Despite the fact that the EU has an exclusive competence on 'the establishing of the competition rules necessary for the functioning of the internal market', ${ }^{10}$ and that State aid is explicitly mentioned as an area of EU exclusive power in the declaration annexed to the decision to conclude the UNCRPD, ${ }^{11}$ the Strategy neglects the central role played by the EU in regulating the market and consequently neglects the opportunity to promote accessible technology through State aid. This oversight is, however, counterbalanced by different provisions referring to both the rights of people with disabilities and accessibility in EU State aid law. The 2014 General Block Exemption Regulation (GBER), ${ }^{12}$ which will be discussed further in this article, includes several references to the UNCRPD, to the EDS 2010-2020, and to accessibility. However, these references are limited to the provisions on accessibility of cultural goods and heritage, and to those articles on aid related to the training and hiring of workers with disabilities (which largely recite the previous articles included in the 2008 GBER: Ferri and Marquis 2011). ${ }^{13}$ It is therefore safe to suggest that, up to now, EU State aid law and policy has not been included in the toolbox of 
policy options available to the Commission (or, more precisely, to the Member States) to improve the availability and choice of AT and universally designed products for their intended market (Ferri 2015). It may be argued that this is a likely consequence of the restraint of the Commission in boosting the 'supply side', i.e. encouraging the production of accessible goods as a whole. This is also in line with the 'less-aid' policy and the purely economic approach to State aid professed by the Commission in the EU State Aid Modernisation (SAM) ${ }^{14}$ which will be discussed in the next Section.

Against this background, this article argues that EU State aid law has a great, yet unexplored, potential to ameliorate the availability of accessible goods and services across the EU. Building upon a previous piece of research (Ferri 2015), this article attempts to demonstrate how EU State aid law can be meaningfully used to incentivize developers to increase the production of accessible goods, to adjust or reduce prices and to provide consumers with a greater selection in a greater number of marketplaces. It further relies on the hypothesis that the accessible technology market(s) present(s) common trends and identifiable failures, which may be addressed and overcome by a more active role of the State within the framework of a more targeted EU State aid policy. This hypothesis is grounded in economic evidence and draws inspiration from the economic study recently published by Mariana Mazzuccato in the book The Enterpreneurial State (Mazzucato 2011), which the title of this work echoes.

Further to these introductory remarks, this article is divided into six sections, followed by a brief series of concluding remarks. Section 2 provides an overview of the EU system of State aid law, with the intent of establishing the pertinent legal context. Section 3 briefly addresses the main characteristics and failures of the accessible technology market. Section 4 discusses why State aid might be necessary to create an EU-wide market for accessible products. It identifies the rationale behind creating a more prominent role for the State in addressing and overcoming market failures. Sections 5 and 6 address the role of the EU in controlling State aid. In particular, Section 5 explores whether and to what extent the past legal framework has allowed Member States to subsidize accessible technology. It will further explore and place a particular emphasis on aid assessed under Article 107(3)(c) TFEU - in light of the 2006 Research, Development and Innovation Framework (2006 R\&D\&I Framework), ${ }^{15}$ as well as in light of the 2006 Guidelines on State aid to promote risk capital investments in small and medium-sized enterprises (Risk Capital Guidelines). ${ }^{16}$ It also focuses on the arguable role of 2008 GBER in allowing Member States to use public subsidies to encourage the production of accessible technology. Section 6 discusses the potential of the updated legal framework, which entered into force in July 2014, namely the new R\&D\&I Framework ${ }^{17}$ and risk finance aid guidelines, ${ }^{18}$ and the novel GBER. The article concludes by reflecting upon the potential of EU State aid to improve the accessible technology market and ultimately contribute to promoting the rights of people with disabilities.

\section{State aid in the EU: an overview}

Subsidies and other forms of public intervention cannot be adopted freely by the EU Member States. Since its inception, the EU has continually introduced rules that control State aid. These, often significant, constraints have sought to restrict national policymakers in how they grant money to markets and market actors in order to ensure the functioning of the internal market. Article 107(1) TFEU provides that any aid granted by a Member State or through state resources that distorts or threatens to distort competition by favouring certain undertakings or the production of certain goods is incompatible with the internal market, insofar as it affects trade between the Member States. In other 
words, State measures are prohibited if the criteria listed in Article 107(1) TFEU (namely, transfer of State resources, economic advantage, selectivity, distortion of competition, and effect on trade between Member States) are satisfied (Plender 2004; Quingley 2009; Biondi 2013; De Cecco 2013). However, Art. 107(2) and (3) TFEU sets out exemptions to the general ban contained in Art. 107(1) TFEU on the premise that markets are incapable of being entirely self-regulating at all times, and this may necessitate some intervention from the State for these same markets to operate more effectively, raise consumer welfare, and/or to protect and promote specific rights or values. Art. 107(2) TFEU specifies a number of cases in which national support measures are permissible. ${ }^{19}$ These categories, which are listed in Article 107(2), are automatically exempted from the prohibition of Article 107(1) TFEU and are called de jure derogations. Art. 107(3) TFEU states that some other forms of aid may be considered compatible with the internal market. Among them, it lists: aid to promote the economic development of areas where the standard of living is abnormally low or where there is underemployment (lett. a), aid to promote the execution of a project of common European interest or to remedy a serious disturbance in the economy of a Member State (lett. b), and aid to facilitate the development of certain economic activities or of certain economic areas, where such aid does not adversely affect trading conditions to an extent contrary to the common interest (lett. c). ${ }^{20}$

The EU's supervisory role of State aid is based on a system of ex ante authorization by the Commission pursuant to Art. 108 TFEU. This means that measures constituting State aids are prohibited unless the Commission has been notified of such measures, has assessed them under the scope of Art. 107(2) or (3) TFEU, and has finally approved them. Aid falling under the de jure derogations set forth in Art. 107(2) TFEU are generally considered compatible with the internal market. The case law of the Court of Justice has repeatedly demonstrated that Art. 107(3) TFEU must be interpreted strictly. ${ }^{21}$ However, it is commonly acknowledged that the Commission has significant discretion in carrying out an assessment of economic, technical and policy considerations, and has quite a wide leeway when evaluating whether the aid is appropriate and proportionate to achieve relevant policy goals. ${ }^{22}$ To increase legal certainty and predictability in the assessment under Art. 107(3) TFEU and in the efforts of identifying common principles for evaluating the compatibility of an aid measure with the internal market, the Commission has also passed various guidelines, mainly in the forms of 'communication' (Stefan 2013). ${ }^{23}$

For the purpose of this analysis, it is worth noting that the Commission has defined both conditions under which public funding of R\&D\&I generates common benefits while limiting the negative effects from distortions to competition, and the criteria to assess State subsidies to SMEs in the form of risk capital. ${ }^{24}$ In a nutshell, the new Framework for State aid for R\&D\&I, which entered into force in July 2014, is underpinned (as was its predecessor) by public interventions that are effectively targeted towards growth-enhancing activities, which limit market distortions that would undermine the competitive nature of the internal market. In the Impact assessment document, the Commission plainly states that its actions must 'ensure both that companies can receive the support they may need to address those market failures that hamper R\&D\&I activities and that aid is limited to the minimum necessary'. ${ }^{25}$ This approach has not substantially altered, but the new framework seeks to provide clarity and ensure that State aid incentivizes industry to undertake additional R\&D\&I investments. The 2014 Guidelines on State aid to promote risk finance investments intend to address the difficulties faced by SMEs in gaining access to finance, which continue to be exacerbated in this period of financial crisis. The concept of market failure in SMEs' access to finance is central to the Guidelines. They do however balance the need 
to address market failures against the need to make European SMEs more competitive in the global marketplace without unnecessarily distorting competition.

Treaty rules and guidelines are complemented by a composite system of secondary regulations. It is worth remembering that Art. 109 TFEU allows for the adoption of secondary legislation in the field of State aid. Under this provision, the Council adopted Regulation 994/98, ${ }^{26}$ i.e. the Enabling Regulation, which has empowered the Commission to adopt individual regulations in which it declares certain types of aid to be lawful and exempts them from the obligation of prior notification. ${ }^{27}$

Although the Treaty provisions themselves have remained relatively static, State aid law and policy as a whole is subject to constant development. The enactment of new guidelines and regulations is part of a deep process of modernization to achieve 'less and better targeted State aid'. One of the aims of the State Aid Modernization (SAM) package is an 'assessment of genuine market failures'. The Commission has often stated that aid is justified only where it will correct market failures, although the meaning of this particular concept has yet to be defined, and, according to scholarship, the concept is not applied in a consistent and clear manner (Lang 2014). The SAM places a greater emphasis than before on the balancing test that the Commission must engage with in order to balance the negative impacts of the aid measure on competition with any positive impacts on remedying market failures (or on achieving other policy objectives). The SAM package intends to encourage schemes that support growth, but attempts to put clear limits to aid measures that do not produce real benefit and distort competition. This commitment is clearly reflected in the soft law mentioned above (both the 2014 R\&D\&I Framework and the Risk Finance Guidelines), as well as in the regulations enacted.

It is worth recalling that, from 2001 to 2006, the Commission approved a series of exemption regulations, ${ }^{28}$ consolidated and replaced by the 2008 GBER, in force until 30 June 2014 (Deiberova and Nyssens 2009), when it was replaced by a new 2014 GBER. $^{29}$ The new GBER has extended the scope of aid that is exempted from prior notification, in order for the Commission to refocus on those cases most likely to have a distortive effect. As with its predecessor, the new GBER covers several categories of aid including aid in the form of risk capital, aid for research, development and innovation, and lays down the conditions under which state aid can be considered compatible with the internal market, and exempted from notification requirements. ${ }^{30}$ In addition, the thresholds up to which R\&D\&I aid can be granted without prior Commission scrutiny have been significantly increased: for example, aid of up to $€ 15$ million can be awarded for enhancing the prototyping phase, without prior approval. ${ }^{31}$ The threshold is even higher for cross-border projects.

It thus appears that the present trend of EU State aid law and policy acts to foster 'sustainable, smart and inclusive growth in a competitive internal market', while ensuring that only 'good aid' is granted, i.e. aid that is well-designed, targeted at visibly identified market failures and objectives of common interest, and are the least distortive option available (Segura Catalán and Clayton 2013). ${ }^{32}$

\section{The accessible technology market(s): trends and failures}

EU State aid policy is more than ever focused on the concept of market failures. Despite any (grounded) criticism, which might be raised against the Commission practice, it is clear that the SAM wants inter alia to restrain aid to those situations in which the market does not work properly if left alone - limiting subsidies that would be ineffectively implemented by Member States. Thus, the next necessary step in this analysis is to ascertain whether in the case of accessible technology there is a market failure to 'heal'. 
Before discussing whether there is a market failure, it seems useful to ascertain whether we can deal with a unique accessible technology market. As discussed in the Editorial of this Special Issue (Ferri, Giannoumis, and O'Sullivan 2015), 'accessible technology' encompasses both universally designed technological goods and AT, which might be seen as complementary products (Vanderheiden 1998; Bauer and Elsaesser 2012). Owing to the large range of different products that can be qualified as accessible technology, it is impossible to conceive and identify a singular and unique 'relevant market' of accessible technology in the meaning currently employed within competition law analysis. ${ }^{33}$ Since the publication of the 1997 'Commission notice on the definition of relevant market for the purposes of Community competition law', ${ }^{34}$ the relevant market has been defined by referring to two specific dimensions: the product and the geographic market. The product market embraces all those products and/or services that are regarded as interchangeable or substitutable by the consumer by reason of the products' characteristics, their prices and their intended use, and this is clearly not applicable to accessible technology as defined above. Indeed, we could hardly even speak of an AT market. AT comprises all the devices that support functional needs of people who experience difficulties linked to disability or ageing, including medical devices, and encompasses diverse products (from low-tech devices, such as wheelchairs to high-tech products such as cochlear implants), which are not interchangeable by their very nature. Universally designed technologies also encompass a diverse range of products. The relevant geographic market is usually defined as the area in which the firms concerned are involved in the supply of products or services and in which the conditions of competition are sufficiently homogeneous. Again, in the case of accessible goods, we could individuate several national and/or local overlapping markets. Although the annual value of the EU market for assistive devices as a whole has been estimated at $€ 30$ billion, ${ }^{35}$ in the field of AT, with the notable exception of hearing aids, the main producers are small and medium enterprises (SMEs) which usually sell their products locally or nationally (Stack et al. 2009; Giannoumis and Kline 2014). Universal design has not been sufficiently operationalized and it is difficult to speak about universally designed goods. Those goods that attempt to respect universal design principles represent a niche segment of the EU market (Gassmann and Reepmeyer 2008), and if they are produced, they are sold mainly at the national or local level.

However, these multifaceted and internally diversified markets for universally designed technology and AT present common trends and failures that might justify a State intervention and a specific or explicit EU State aid 'provision' to allow it.

The AT market(s) as a whole, despite experiencing an upward trend (AEGIS 2009), appears underdeveloped. There is a need for further research and development (R\&D) to improve existing products and create new ones. Whilst several experimental projects already exist, ${ }^{36}$ few new products are actually produced and are therefore incapable of reaching the market. Thus, despite the efforts of these research and development projects, the AT currently sold is often old, deficient or unsatisfactory. ${ }^{37}$ In cases of particularly severe physical disabilities, the AT currently on the market is frequently inappropriate for the individualized needs of the person. Foley and Ferri (2012) note that while 'massmarket technologies are typically designed for broad (non-disabled) audiences, assistive technology is designed around assumptions about disabilities and disabled users that may or may not be accurate'. ${ }^{38}$ It is also highlighted that more research on usability and on how devices function in society is needed in, and that user-centred design (UCD) approaches that encourage consideration of all users (Wallach and Scholz 2012), including carers and trainers, should be improved and adopted by industries developing and producing AT (Lenker et al. 2013). However, companies are generally unwilling to develop 
products that have a high 'technical complexity' and thus necessitate higher advanced cost outlays without an express demand. Secondly, as highlighted by the 'European Thematic Network on Assistive Technologies and Inclusive Solutions for All', people with disabilities are not viewed as potential consumers, ${ }^{39}$ but rather as people in need of assistance. This vision is reinforced by the fact that AT are mainly provided through health or social services, or, more generally, support schemes for people with disabilities (Service Delivery Models - SDMs). SDMs are either medically or socially oriented, rather than consumer oriented. This means that the service provider acts as an intermediary between the supply (available assistive products) and the final end-user (person with disabilities), and the final end-user does not decide on whether the assistive product meets their needs. SDMs usually include lists of eligible products, which often are not the most advanced (or the newest) (Giannoumis and Kline 2014). ${ }^{40}$ Harris (2010) highlights that items given to users and funded wholly through the public system were 'prescribed' by professionals and the users did not have the ability to express even a preference for the item 'prescribed'. By comparison, those users in the private purchase arena are overwhelmed with the available choices, and deciding between high and low-end products, the latter often constituting a lower quality device, is often difficult. ${ }^{41}$ Deloitte, in its study on assistive ICT, argues that in some countries little or no assistive ICT solutions are part of the 'positive list' of procured products through the SDMs. Hence, SDMs themselves function as a barrier to innovation (Deloitte 2003). Overall, the important 'chicken-and-egg' challenge in the AT marketplace proves that industry (and more specifically any SME) is reluctant to invest in products without an expressed demand from service providers, whereas service providers cannot get engaged unless there are products to work with.

UD emerged from the convergence of barrier-free environments, accessible design and AT, and their importance has been greatly emphasized by disability studies. The latter have evidenced the role of UD as a way to set aside AT, which operates from a deficit based, medical model orientation, resulting in an "apartheid of "special needs" (Goggin and Newell 2003). However, according to Gassmann and Reepmeyer (2008), private industry has very little experience with UD. Foley and Ferri (2012) affirm that UD itself presents a significant problem since it 'suggests the possibility of universal access, even when products that have gone through a UD design process might not be universally accessible in practice'. The costs of UD are still unknown, and common concerns about adopting UD are that 'it will slow down the time to market, and increase design, manufacturing, and customer support costs' (Vanderheiden and Tobias 2000). As extensively argued by Bauer and Elsaesser (2012), improving a technology to make it 'more universal' means increasing the level of impairment 'tolerated' in its use, and thus increasing the technical complexity, will correspondingly increase costs. These costs constrain the private sector's engagement in UD. Even though, in the long run, UD should gain more commercial relevance because it is potentially appealing not only to buyers with disabilities, but also to elderly customers, and ideally to all consumers' groups, UD may be still perceived by some companies as a special interest of people with disabilities, who, as mentioned before, are not viewed as potential consumers.

The fast pace of technological change is also an issue for both universally designed products and AT: by the time an accessible version is developed, mainstream technology has often been updated or otherwise changed (Foley and Ferri 2012). In some cases, technology is more accessible in its earlier version than in later iterations: for example, Internet Explorer now has fewer accessibility features than earlier iterations (Ellis and Kent 2011). ${ }^{42}$

In conclusion, even where one considers accessible technology to constitute a patchwork of markets, common trends and failures appear. Accessibility is not always a 
primary concern in the development of new technologies, and preconceptions about people with disabilities as people in need rather than consumers remain the dominant narrative. In addition, industries seem to underestimate the fact that technology designed for disability does not have to be segregated to any particular market: 'there are many examples of the crossover appeal of technologies for disabled users, making it difficult to draw a hard and fast line between what is and is not considered assistive technology' (Foley and Ferri 2012). Overall, in the development cycle of new technologies, there is often industry unwilling to engage in product innovation ${ }^{43}$ and in experimental products that require massive costs to provide technology that is usable by people with disabilities. This challenge echoes a common trend in the technology sector: the decision to innovate often takes place under great uncertainty, and the path from an idea to a marketable product is quite long. Thus, the main market failure in the accessible technology market is the socalled 'valley of death' which exists between basic research (often academic research) and the commercialization of a new product. ${ }^{44}$

\section{The EU, the 'entrepreneurial state' and accessible technology}

\subsection{A 'demand-side approach': the dark side of the moon}

The main market failure of the accessible technology market(s) can be roughly identified as the 'valley of death', i.e. the substantive lack of R\&D, which leads to the commercialization of new products on the EU market. This failure, which is typical of the high tech market, is actually evident in both AT and UD ICT, because of the unwillingness of private industry to engage in developing new technology with undefined costs and undetermined demand. It is commonly acknowledged that the AT market is currently subject to great change and that more usercentred and flexible approaches are being generated. However, a lack of R\&D in private industries is still tangible. This deficiency of R\&D is even more evident when it comes to universally designed products. Overall, there are very few innovative accessible goods sold on the internal market at affordable prices, and the market itself is still highly fragmented.

As previously mentioned, the EDS 2010-2020 somewhat acknowledges, though not explicitly, the existence of a market failure, especially with regards to AT. Nonetheless, it focuses on improving the demand-side of accessible technology through legislation and standardization, rather than incentivizing production. Building upon well-rooted practice, the Commission intends to present legislative proposals aimed at improving and complementing existing laws (Boyle 2009; Waddington 2009; Lawson 2010), to address different aspects of accessibility in transportation, in ICT or in public procurement, using Article 114 TFEU as a legal basis. ${ }^{45}$ The main short-term objective is a cross-cutting 'European Accessibility Act'. This piece of legislation should not only address public authorities that procure goods and services, but also private parties, i.e. manufacturers, distributors, sellers and services providers and should state, at various levels, duties to deliver accessible products and services (Ahtonen and Pardo 2012; Charitakis 2013). ${ }^{46}$ Thus, the Strategy should embrace the view that increasing the demand for these accessible products should indirectly support an increase in the supply of the same, and ultimately stimulate a virtuous market circle, without the need of direct 'supply side' measures, such as subsidies or tax credits to producers, which might alter free competition.

From this perspective, the main issues to be addressed are whether these tools are actually sufficient and as effective as the Commission states to overcome the market failure outlined above, and whether they are capable of doing so by 2020. The answer to these two questions would appear to be negative, for two somewhat overlapping reasons. 
First, on a substantial point, harmonization measures might certainly reduce fragmentation on the EU market, but do not have a direct effect on R\&D and the commercialization of new products. In this respect, Faeh's analysis seems particularly relevant (Faeh 2013). In investigating the pharmaceutical sector in the EU, the author concluded that it is very difficult to establish a correlation between market harmonization and investment in innovation or R\&D. He states that, whilst a certain level of harmonization is fundamental to incentivizing producers to launch new products in the Union market, only financial incentives can contribute substantially to $R \& D$ investments and their resulting innovations. Faeh affirms that it is difficult to transfer the outcome of his analysis to other innovative sectors (as they are subject to other rules and framework conditions). However, although acknowledging the peculiarity of the pharma sector (especially with regards to pricing and reimbursement of medicinal products), it seems that this conclusion might be applicable to the field of accessible technology, bearing in mind that many ATs are medical devices strictu sensu. With regards to UD, as highlighted by Vanderheiden and Tobias (2000), accessibility obligations imposed by means of legislation (i.e. harmonization legislation) might improve the design of mainstream products, but is likely to cause the industry to stop at exactly those targets provided for in the legislation, preventing further innovation.

Secondly, from a pragmatic perspective, EU legislation takes a long time to be implemented and take effect. The case of the 'European Accessibility Act' is exemplary. At this stage, notwithstanding the renewed commitment expressed by the Commission at the European Day of Persons with Disabilities on 3 December 2014, it is still fairly uncertain what the real scope and actual content of this act will be and when a full proposal will be divulged. As denounced by the European Blind Union (EBU), in its 2015 work programme, the Commission did not even mention the European Accessibility Act. Similarly, the new Directive extending the material scope of the provisions against discrimination on the ground of religion and belief, disability, age and sexual orientation beyond the area of employment, into the fields of social protection, including access to and supply of goods and other whose proposal was released by the Commission in 2008, is 'buried under sand'. ${ }^{47}$ This proposal does not contain express accessibility obligations, but conceptualizing 'denial of reasonable accommodation' as a form of discrimination, in compliance with the UNCRPD, could indirectly boost accessibility and the demand of accessible technology.

\subsection{A 'supply-side' approach}

The demand-side approach adopted by the Commission seems insufficient and not fully capable of tackling the market failures related to accessible technology. But this still does not answer the question of whether specific supply-side measures, and particularly State aid, are needed to bridge this gap. There are three main arguments to support the explicit inclusion of State aid among the Commission's policy options to nudge the market in a more accessible direction.

First, supply-side measures might fit in a framework together with demand-side tools, and effectively complement them, especially with regard to the high-tech market. Mazzucato's analysis is particularly relevant in this respect. While her discussion is complex and not conducive to providing succinct overviews, for the purpose of this investigation, we can refer to a few key points. Even though Mazzucato does not encourage cutting blanket support to small firms or a wide R\&D tax credit, she envisages a more complex strategy in which the 'entrepreneurial State' plays an active role in generating innovation-led growth. In this vision, 'the state's role cannot be limited to that of planting seeds that can be subsequently relied on to grow freely'. In her thought-provoking pamphlet, 
Mazzucato contends that ' $[\mathrm{n}]$ ot only has government funded the riskiest research, whether applied or basic, but it has indeed often been the source of the most radical, path-breaking types of innovation' (Mazzucato 2011). She claims that 'often public sector funding ends up doing much more than fixing market failures ... It leads the growth process rather than just incentivising or stabilising it'. In applying this to the biotech industry in the US, Mazzucato shows that, on the one hand, the knowledge base, which biopharmaceutical companies are dependent on, has developed, to a greater extent, from government investment than from business. She also shows that this investment complemented venture capital and public equity funds, which hand been poured into the industry. This conclusion seems particularly pertinent for, and transferable to, the accessible technology market, which needs a more complex action that goes beyond simply funding basic research and setting regulations. This finding is even more obvious, with regards to UD, given that only supply-side and demand-side incentives provided through public policy might overcome compounding high cost factors (Bauer and Elsaesser 2012).

Secondly, 'supply-side' measures, and namely State aid (including measures as inter alia subsidies, tax credits, or public venture capital $)^{48}$ complement other research policies, which are affixed to basic research. At the EU level, it is undeniable that several promotional initiatives to boost R\&D in the field of accessible technology (especially on AT) ${ }^{49}$ have been put in place. The EU has fostered innovation and Key Enabling Technologies (KETs), ${ }^{50}$ in line with the EU2020 Strategy ${ }^{51}$ and Innovation Union. ${ }^{52}$ The latter Innovation Union flagship initiative is intended to incentivize R\&D\&I that addresses the challenges faced by society, including but not limited to health and demographic change (especially the increasing elderly population). In this respect, the EU is also advancing a European Innovation Partnership on Active and Healthy Ageing, ${ }^{53}$ and is discussing a more active participation of the EU in the Ambient Assisted Living Joint Programme. ${ }^{54}$ The latter focuses precisely on the 'valley of death' link of the innovation chain where research results need to be translated into new products and services ready to enter the market. However, these initiatives in most cases have not led to the commercialization of new products, and their outcomes are most likely long-term results. At present, these research initiatives, which are capable of bringing about affirmative change, have not yet improved the overall availability of new products at costs affordable for most consumers. The 'valley of death' therefore has yet to be eliminated or significantly alleviated, as general EU State aid law, as already acknowledged, allows only certain R\&D\&I subsidies. Other forms of more direct State intervention on the market to improve R\&D on accessible technology could complement the efforts already in place and could be considered in compliance with the EU legal framework.

Third, 'supply-side measures' might have side effects, altering competition. However, this is a well-known drawback that the Commission is already trying to tackle in the SAM. The lack of any reference to State aid with regards to accessible technology is thus not reducible to the Commission's concern that Member States engage in rare subsidies. In addition, it appears quite questionable that a far less cautious approach has been adopted with regard to standardization in the context of accessibility, which is also problematic, not only because of its legitimacy, but also for its potentially anticompetitive effects. ${ }^{55}$

\section{Has state aid to R\&D fostered accessible technology up to now?}

\subsection{Setting the scene}

Having discussed the prospective benefits of a 'supply-side approach', the potential for State aid to boost the EU accessible technology market is best discussed by looking at 
how, up to now, EU State aid law has allowed Member States to address the market failure common to AT and UD technology. As this market failure largely takes the form of the previously discussed 'valley of death', we will look at how the 2006 R\&D\&I Framework, applicable as of 1 January 2007 until June 2014 and replaced by new Framework, has pushed the market in a more accessible direction, despite any specific engagement on accessible technology. Since ATs are mainly produced by SMEs or even micro-enterprises, attention will also be given to aid assessed in line with the risk finance guidelines, which, as highlighted in Section 2, were underpinned by the rationale of facilitating access to risk capital through the use of public funds, overcoming the unwillingness to accept risks in high technology markets due to extreme uncertainty, resulting from the impossibility of predicting results and profits.

\subsection{State aid assessed under the R\&D\&I framework}

The 2006 R\&D\&I Framework defined the Commission's margin of appreciation in assessing the compatibility of State aid under Article 107(3)(c) TFEU, or under Article 107(3)(b) TFEU (in the case of research that contributes in a clear and identifiable manner to the EUs overall interests). ${ }^{56}$ It encompassed various types of aid aimed at fostering 'fundamental research' (experimental or theoretical work undertaken to acquire new knowledge), 'industrial research' (research for developing new products, or for bringing about a significant improvement in existing products), and 'experimental development' (the acquisition and use of existing scientific, technological, business for new, altered or improved products, processes or services). In essence, the types of State aid allowed under this Framework were: aid for R\&D projects; aid for technical feasibility studies; aid to cover SMEs' costs relating to intellectual property rights (IPRs); aid to young, innovative companies; aid in support of organization and process innovation in the service industry; aid for recourse to innovation support and advisory services; aid to SMEs for temporary employment of highly qualified personnel and aid for innovation clusters (for 'groupings of independent undertakings - innovative start-ups, SMEs and large undertakings as well as research organizations - operating in a particular sector and region and designed to stimulate innovative activity).

For each type of aid, the 2006 R\&D\&I Framework established aid intensity ceilings, specifying the percentage of the eligible costs, and stated that the aid should 'result in the recipient changing its behaviour so that it increases its level of R\&D\&I activity'57 and be proportionate. It also provided guidelines that allowed the Commission to verify the extent of any potential market distortions (in relation to both competition and any effect on trade), and to validate that the overall balance is positive.

The 2006 R\&D\&I Framework, as it remains under the current regime, was a horizontal measure and was not directed at any definitive sector. The 2006 R\&D\&I Framework instead addressed the common objective and interest of promoting R\&D\&I and did not intend to tackle other policy goals. R\&D\&I was considered per se an objective to pursue, due to the potential for economic growth, but this overlooked the functional benefit in the provision of other public goods (such as public health, accessibility, environmental protection) that may arise from such measures.

This legal framework has allowed Member States, even in a period of economic crisis, to heavily subsidize the technological sector as a whole and, in particular, R\&D\&I activities of high-tech enterprises. ${ }^{58}$ In the last ten years, the Commission assessed and approved a plurality of schemes directed to boost high tech development, ${ }^{59}$ such as the German scheme Richtlinie über die Gewährung von Zuwendungen für Forschung, Innovation 
und Technologie des Landes $N R W,^{60}$ or the Spanish schemes INNOTEK ${ }^{61}$ and Notificación Plan Nacional de Investigación Científica, Desarrollo e Innovación Tecnológica 20082011. ${ }^{62}$ Although it is very likely that these schemes subsidized inter alia accessible technology development, none of them included accessibility, UD and AT as key features, and in its assessment (unsurprisingly) the Commission never considered the goal to promote accessibility, or market failures specific to accessible technology (Ferri 2015).

Member States also promoted R\&D\&I of nanotechnology, which is particularly relevant in the field of assistive medical devices (e.g. implants, prosthetics or brainmachine interfaces). For example, the Commission approved the French aid to STMicroelectronics (ST) for the development of new technologies in the nanoelectronics sector. The Commission stated that the French measure, aimed at developing new technologies for the design and production of integrated circuits and at strengthening the Crolles-Grenoble cluster as a global leader in the field of advanced CMOS (Complementary Metal-OxideSemiconductor), is in line with EU rules on state aid. Again, none of the aid assessed was specifically targeted at accessible technology. However, nanoelectronics is a 'key enabling technology', underlying innovation in many branches of industry, and semiconductors are omnipresent in high-speed communications accessible to all, cloud computing, smart power grids, or e-health (Ferri 2015). ${ }^{63}$

This horizontal economic approach adopted by the Commission did not encourage Member States to specifically tackle the development of accessible technology. Nevertheless, at the same time it did not impede Member States in putting in place a measure to pursue a specific policy goal (i.e. accessibility), in so far as this measure fulfilled the requirements laid down in the 2006 R\&D\&I Framework. However, the Commission embraced the view that aid measures aimed at R\&D\&I activity 'close to the market' are likely to develop negative effects on competition, and in particular significant 'crowding out effects'. This made, on the one hand, the Commission more suspicious (and more careful in its assessment) of aid measures that sustain R\&D\&I activities, which are adjacent to the commercialization of the product or the service. On the other hand, it rendered Member States unwilling to invest public money at an intermediate stage of development, between basic research and commercialization of a new product, and ultimately left unresolved the 'valley of death' within the technology sector.

\subsection{State aid assessed under the risk capital}

The rules by which State subsidies to SME in the form of risk capital are assessed, in force until June 2014 and recently substituted by new guidelines, are premised on the fact that there is no general risk capital market failure in the EU, but there are gaps for some types of investments at certain stages of an enterprises' development.

The Guidelines implemented a test where Member States (and the Commission in assessing the aid) could balance the potential positive and negative effects of the aid. In particular, a risk capital measure was compatible with the internal market when the following conditions were met. First, the investment tranches should not exceed $€ 2.5$ million per enterprise per year. Second, the aid should be granted up to the expansion or start-up stage of the SMEs. Third, at least $70 \%$ of the total budget of the risk capital measure should be in the form of equity and quasi-equity instruments. Fourth, at least $50 \%$ of the funding should be provided by private investors. Finally, the risk capital measure should ensure that the decision to invest into target companies are profit-driven and the management of a risk capital measure or fund must be effected on a commercial basis. 
The Risk Capital Guidelines highlighted that the national measure was to pursue an objective of common interest, such as the protection of the environment, economic growth, employment and cohesion. Although this is not an exhaustive list, it is worth noting that no explicit reference to accessibility was made. This of course was mirrored in the national schemes. Similar to what arose under the R\&D\&I Guidelines, in the assessment of these schemes the Commission did not consider the goal of promoting accessibility, or market failures specific to accessible technology, even though, in many instances, the measures approved were likely to boost inter alia accessible technology production. Relevant examples include the Bavarian Risk Capital Scheme 'Clusterfonds Seed GmbH \& Co. $K G$ ' to support technology focused micro- and small enterprises, and namely to allow them to conduct R\&D for the first prototype or the 'proof of concept' (initial concept), ${ }^{64}$ and the Spanish INVERTEC, which sought to promote the projects of innovative undertakings and the projects of technologically-based undertakings in Catalonia. ${ }^{65}$ Another pertinent scheme is the German HighTech Gründerfonds II, a public-private partnership to foster investments in high-tech firms that was approved by the Commission in September $2011 .{ }^{66}$ In particular, this is a venture capital fund, the biggest investor of which is the German State through the Ministry of Economics. The fund materially applies to three different technological fields: IT, Life Sciences and Engineering. The eligibility requirements for obtaining an investment echo the Framework and include, other than the more formal requirements (concerning age and location of the potential investee), a technological focus, an entrepreneurial team, and a good market opportunity. Universal Design, or accessibility are not a condition, although they might increase the potential to receive investment. The Fund has up to now funded several companies producing different types of AT: for example, Desino, an entrepreneurial team who developed an active wheelchair preventing and reducing lower back pain through its manual hybrid drive and movable seat; ${ }^{67}$ Exelonix, an enterprise developing assistance systems for elderly people, which offers home emergency call functionality along with easy-to-use internet and communication applications that will enable participation in the information society without barriers; ${ }^{68}$ and Synoste which develops novel, implantable, patient friendly, cost-effective and reliable medical devices for correcting skeletal deformities. In some instances, the schemes approved by the Commission are targeted at medical technologies. This is exemplified by the German investment fund Technologiegründerfonds Sachsen (TGFS) put in place by the Saxony Land ${ }^{69}$ and approved in 2007. The TGFS aimed to provide capital to roughly 60 economically stable innovative small and micro enterprises, and especially to technology-oriented founders, also through equity and quasi-equity investments. Although not explicitly intended to foster accessible technology, the scheme focused inter alia on microelectronics and medical technology (which includes medical assistive devices).

The Commission in its assessment is prone to over-emphasizing the existence of a market failure. This purely economic approach has certainly been conducive to sustaining technological industry and innovation. It does not however seem per se sufficient to direct or incentivize Member States to subsidize the development of accessible technology.

\subsection{The GBER and aid to foster accessible technology}

The 2008 GBER covered several categories of aid relevant to the EU2020 goals that could be used by Member States to nurture technological innovation. It encompassed inter alia investment related to SMEs, aid in the form of risk capital, and aid for R\&D\&I. The 
2008 GBER established the conditions under which State aid could be considered compatible with the internal market and exempted from prior notification. The aid should be transparent within the meaning of the GBER, ${ }^{70}$ respect the thresholds laid down in Article 6, and have an incentive effect (Article 8 GBER).

Aid in the form of risk capital was covered by Section 6 (Articles 28 et seq.), while aid for R\&D\&I was covered by Section 7 (Articles 31 et seq.) of the 2008 GBER. According to Article 29, risk capital measures should take the form of participation in a profit-driven private equity investment fund, managed on a commercial basis, and the investment to be made by the investment fund was not to exceed $€ 1.5$ million per undertaking per year. Similarly to what was provided in the Risk Capital Guidelines, at least $70 \%$ of the total budget invested in SMEs should be in the form of equity and quasi-equity instruments, and at least $50 \%$ of the funding should be provided by private investors. ${ }^{71}$ Article 31 exempted from notification aid for fundamental research, industrial research, and experimental development. The aid intensity ceiling amounted to $100 \%$ of the eligible costs for fundamental research; $50 \%$ of the eligible costs for industrial research, $25 \%$ of the eligible costs for experimental development. Aid intensities for industrial research and experimental development could be increased in case of aid granted to SMEs, in case of projects that involved collaboration between at least two undertakings, between an undertaking and a research organization, and in case of industrial research, when the results of the project were widely disseminated. ${ }^{72}$

Undoubtedly, the 2008 GBER allowed for several public financial measures supporting SME and boosting R\&D\&I, but the impact on the accessible technology market seems limited. Under Articles 28 and 29, Member States put in place different risk capital measures to boost the high-tech sector, such as the Austrian 'Oberösterreichischer Hightechfonds ${ }^{73}$ or the Italian 'Fondo Nazionale per l'Innovazione - Capitale di rischio' ${ }^{74}$. Even though these kinds of schemes are quite likely to affect the development and production of accessible technology, none of them targeted accessible technology, and there is no clear evidence that they have actually contributed to increasing accessibility.

Other measures, allowed under Article 31 GBER, were relevant for subsidizing accessible technology, but their impact remains limited. For instance, few Member States provided direct grants for industrial research and experimental development in the field of AAL: notable examples are the Danish AAL - Ambient Assisted Living, and the Italian Regional scheme (Marche) 'Casa intelligente per una longevità attiva ed indipendente dell'anziano'. Under the UK's 'Technology Strategy Board Research, Development and Innovation scheme' numerous calls for funding AAL projects (together with other funding opportunities to design technology-based products and services) were launched. The Bavarian scheme 'Hochtechnologien für das 21. Jahrhundert ${ }^{75}$ currently supports research and development in the fields of life sciences, information and communication technology, microsystems technology, materials science, energy and environment, mechatronics, nanotechnology and process and production technology in accordance with information processing and information systems, and software development. Even though the scheme is not targeted to accessible technology, it is intended to subsidize the development of key components for communication systems, including microelectronics and innovative applications such as multimedia, or Intelligent Home Automation (which might fall within the broad group of accessible technology). In addition, the scheme unambiguously covers research and experimental development projects in the area of 'Gerontotechnologie', innovative technologies for robotics in the nursing field, for accessible home automation and for other procedures and methods of preservation and enhancement of quality of life and independence. $^{76}$ 


\section{The new rules: is the $\mathrm{EU}$ enhancing an 'entrepreneurial state in the field of accessible technology?}

\subsection{The new guidelines for $R \& D \& I$ and risk capital}

As of 1 July 2014, new guidelines on aid to R\&D\&I have entered into force. As part of the SAM, the Commission deemed it necessary to 'adjust' the scope of the previous Framework, and better clarify the distinction between economic and non-economic activities of R\&D\&I, as well as making the Framework a more flexible instrument and allowing Member States to better support innovation. The new Framework elaborated by the Commission and published in May 2014 is complementary to the GBER, ${ }^{77}$ and aims to increase R\&D spending, as well as to 'facilitate the transition of knowledge and ideas to the market'. ${ }^{78}$ Three features are potentially relevant. First, the Commission has opted again for a horizontal approach, so that the Framework will apply in all sectors governed by the Treaty, and has attempted to grant the Member States more flexibility in implementing R\&D\&I aid. Second, it has better clarified the criteria for distinguishing between economic and non-economic activities (giving Member States greater certainty on the instances where public funding does not constitute State aid). The aid thresholds, beyond which support would no longer be covered by the GBER and would have thereby to be notified to the Commission, have been increased. Third, the R\&D\&I Framework has re-designed the limit of aid intensity; in particular, it allows, for individually notified measures, aid up to $70 \%$ of eligible costs for large companies and $90 \%$ for small companies.

On the one hand, the Commission has adopted a conservative approach, sticking to a general conception that the R\&D\&I is a goal in itself: 'the general objective of R\&D\&I aid is the promotion of R\&D\&I in the Union'. Even though it is mentioned that R\&D\&I aid should contribute to the achievement of the Europe 2020 strategy of delivering smart, sustainable and inclusive growth, as in the previous framework, there are no other policy goals mentioned. The Commission has not embraced the vision that R\&D\&I has to be seen as a means to reach further social goals. ${ }^{79}$ The Commission should have probably acted more courageously and considered that State aid for R\&D\&I might be an important tool for reaching other strategic policy objectives and fulfilling societal needs, within the frame of the 'social market economy envisaged by the Treaty'. ${ }^{80}$ The promotion of the rights of people with disabilities through the development of accessible technology, as one of the end goals that R\&D\&I schemes should adopt, could have been integrated in the Framework. There are several arguments that might support this view. Beside the 'constitutional argument', it cannot be underestimated that increasing accessibility through new technologies is a commitment that the EU has undertaken at the international level by concluding the UNCRPD. Hence, a reference to accessibility, disability rights or even a general mentioning of the UNCRPD would have been in compliance with the international obligation undertaken and the declaration of competence annexed to the concluding decision of the UNCRPD (Ferri 2015). ${ }^{81}$ On the other hand, the Commission retains its vigilant economic appraisal: higher aid levels will only be made available if there is a genuine gap in financing, in order to avoid undue market distortions with regard to competition and trade. In the accessible technology market there is a clear failure that could have been addressed more explicitly in the Framework.

For these reasons, the new Framework does not explicitly incentivize Member States to increase public funding of R\&D\&I (in particular industrial research) on UD and AT, even though it does not discourage them from taking the initiative to do so. The Commission, in substance, leaves to the Member States the choice on whether or not to invest in accessible technology. 
The Commission has also adopted new guidelines setting out the conditions under which Member States can grant aid in the form of risk capital. The new guidelines have an enlarged scope, now including SMEs and companies with a medium capitalization (midcaps), and encompass a wider range of financial instruments, including equity, quasi-equity (already provided for the former 2006 guidelines), loans and guarantees. The Commission has also slightly redesigned the role and the weight of private investors, which is more tailored to the development stage and riskiness of the investment. In particular, the Commission intends to allow higher levels of public support to be extended to company-creation, where the private business finance markets are reluctant to provide the necessary financing. The new guidelines also set out clearer conditions for tax incentives to investors.

In the Commission's estimations, these guidelines should help companies overcome the 'valley of death', when bringing new products and ideas to market. This is particularly relevant for accessible technology production, since, as mentioned above, in the fields of both universally designed technological goods and AT, industry is quite unwilling to engage in experimental products that require considerable advanced financial outlays with a correspondingly low or indeterminate demand. It is hard to predict whether, without any specific drive towards accessible technology, aid measures will be taken to address that particular market. In addition, whilst the Commission pursues an almost exclusively economic approach, the key issue remains how the balancing test is applied in cases of accessible technology, where there is scope for economic analysis and the state aid intends to remedy a market failure.

\subsection{The new GBER}

The new GBER aims to confer to Member States more leeway in granting State aid without prior notification and approval by the Commission (provided that certain conditions are met). It significantly extends the possibilities for Member States to grant aid, but introduces ex post requirements (i.e. evaluation of large aid schemes and transparency on aid measures). The Commission has also included novel categories of aid: among them, it has explicitly crafted 'aid to innovation clusters and aid to process and organizational innovation'. 82

For the purpose of this analysis, it is worth noting that the scope of risk finance aid and R\&D\&I has been broadened. In respect of R\&D projects, notification thresholds have been doubled, and the conditions for support for prototypes and pilot projects have been simplified. However, the Commission focuses on economic growth, rather than on the idea (and goal) of 'inclusive' innovation. As mentioned in the Introduction, the GBER includes several references to accessibility, to the EDS, and to the UNCRPD, but not in relation to R\&D\&I or Risk Capital where they relate to accessible technology. The lack of a specific understanding of the failures and trends within the accessible technology market are as such now part of the new GBER, and it is unlikely to encourage Member States to use State resources meaningfully for AT and UD.

\section{Concluding remarks}

The EDS 2010-2020 has redirected its focus towards improving accessibility and reducing fragmentation in the market of accessible goods and services. However, it has adopted a relatively narrow number of tools that fit these purposes, and has prioritized the use of legislation and standardization as the most suitable means of nudging the market in a more 
accessible direction. One of the main reasons that the Commission might consider State aid an instrument to be 'handled with care' is the fear that it will lead Member States to abuse it as a mechanism and unnecessarily distort competition within the internal market. This is however unsatisfactory, and somewhat alarmist.

In order to negate the 'valley of death', which is a common trend in both the UD and AT markets, as well as to enhance UD, which is still a very niche market, it is necessary to engage with supply side mechanisms as well as stimulating demand. State aid could be a useful tool in this respect. The analysis of the former R\&D\&I Framework and of the Risk Capital Guidelines, of the GBER and of their application has attempted to show that State aid has a great potential to shape the accessible technology market. Its potential in this respect is still largely unchartered.

In addition to the new GBER, both the new R\&D\&I Framework and the Risk Capital Guidelines represent missed opportunities for AT and UD. The Commission sticks to a conception of R\&D\&I as a good in itself, without attempting to valorize certain types of R\&D, and without actually prioritizing innovation towards certain goals, such as accessibility. Despite the fact that there is a clear market failure in both the AT and UD markets and that Member States have a certain room for manoeuvre in subsidizing accessible technology, the purely economic approach falls short of the obligation to create an accessible market that the EU has undertaken by concluding the UNCRPD, and may be detrimental to the goal of 'inclusive innovation' envisaged by the EU2020 Strategy.

\section{Acknowledgement}

This article is part of an ongoing research into the implementation of the UN Convention on the Rights of Persons with Disabilities in the European Union. It builds upon the research conducted when I was 'Lead researcher' of the Work Package 7 of the EU-funded project DISCIT on 'Active Citizenship Through the Use of New Technologies' (www.discit.eu), and on a previous article published in European State Aid Law Quarterly. This article is one of the outcomes of DISCIT. I am grateful to anonymous reviewers for their insightful comments, and to Mr Charles O'Sullivan and to Anthony Giannoumis for their valuable support.

\section{Conflict of interest disclosure}

No potential conflict of interest was reported by the author.

\section{Notes}

1. The Treaty on the functioning of the European Union (TFEU) clarifies the division of competences between the EU and Member States. It distinguishes among three main types of competence: exclusive competences, shared competences and supporting competences. The TFEU draws up a non-exhaustive list of the fields concerned in each case. In fields under the exclusive competences (Article 3 of the TFEU), the EU alone is able to legislate and adopt binding acts in these fields. The Member States' role is therefore limited to applying these acts, unless the Union authorizes them to adopt certain acts themselves. In areas that correspond to shared competences (Article 4 of the TFEU), the EU and Member States are authorized to adopt binding acts in these fields. However, Member States may exercise their competence only in so far as the EU has not exercised, or has decided not to exercise, its own competence. When the EU is given a supporting competence (Article 6 of the TFEU), it can only intervene to support, coordinate or complement the action of Member States. Consequently, it has no legislative power in these fields and may not interfere in the exercise of these competences reserved for Member States (Ex multis Rossi 2012 and Tridimas 2012). 
2. Council Decision 2010/48/EC, OJ 2010 L 23/35. The Council decision to accede to the UNCRPD (see ft. 6) is accompanied by an Annex (Annex II) containing a Declaration of Competence, in compliance with Art. 44(1) UNCRPD. The following matters are declared to be within the exclusive competence of the Union: State aid with respect to both the common market and the Common Customs Tariff and matters affecting its own public administration (e.g., recruitment of staff, etc). The Declaration clarifies that competence is shared between the EU and its Member States with respect to non-discrimination, the free movement of goods, persons, services and capital, agriculture, transport by rail, road, sea and air, taxation, internal market, equal pay for men and women, trans-European network policy and statistics. A list of policy fields (in which the EU can exercise supporting competences) includes vocational training and social cohesion. An Appendix, attached to the Declaration, lists an illustrative set of legislative measures in which Union competence is engaged (at least to some extent) in broad fields such as accessibility, independent living, social inclusion, work and employment, personal mobility, access to information, statistics and data collection and international cooperation

3. Communication from the Commission 'European Disability Strategy 2010-2020: A Renewed Commitment to a Barrier-Free Europe' of 15 November 2010, SEC(2010) 1324 final. The Commission drafted a Commission Staff Working Document to accompany the Strategy. This document outlined the initial plan to implement the EDS 2010-2020 and contained a list of actions foreseen for the period 2010-2015 (SEC (2010) 1324 final).

4. See supra nt. 2.

5. See also Commission Staff Working Document 'Report on the implementation of the UN Convention on the Rights of Persons with Disabilities by the European Union' of 5 June 2014, $\operatorname{SWD}(2014) 182$ final.

6. AAL refers to ubiquitous computing and sensing, ubiquitous communication, and intelligent user interfaces.

7. The Strategy refers to 'Design for all'. In this article, this term is used as a synonym of universal design (UD). Both these terms will be used interchangeably. The origins of Universal Design date back to the early 1950s. Because of the high number of veterans of the Second World War, the public had slowly developed an interest in the needs of disabled people (Gassmann and Reepmeyer 2008). The theorization of 'universal design' started later, namely in 1997, when a group of architects, led by Ronald Mace, laid down the seven rules of universal design: equitable use, flexibility in use, simple and intuitive use, perceptible information, tolerance for error, low physical effort, and size and space for approach and use. This means that the design must be useful and marketable to people with diverse abilities and the same means of use are to be provided for all users. The design must accommodate a wide range of individual preferences and abilities. The use of the design must be easy to understand, regardless of the user's experience, knowledge, language skills, or current concentration level, and must provide necessary information effectively to the user, regardless of ambient conditions or the user's sensory abilities. The design must minimize hazards and adverse consequences of accidental or unintended actions, and can be used efficiently and comfortably and with a minimum of fatigue. The seventh principle alludes to the fact that appropriate size and space is provided for approach, reach, manipulation, and use regardless of user's body size, posture or mobility. Article 2 UNCRPD provides a legal definition of universal design, which constitutes a firm point of reference. This provision states that 'universal design' is 'the design of products, environments, programmes and services to be usable by all people, to the greatest extent possible, without the need for adaptation or specialized design'.

8. See Ferri, Giannoumis, and O'Sullivan (2015). See infra Section 2 of this article.

9. Standards are technical specifications defining requirements for products, production processes, services or test-methods (Borraz 2007; Lemley 2002). They are generally selected by StandardSetting Organizations (SSOs), i.e. industry groups that typically consist of participants in an industry who have expertise in the technologies and products at issue, and evaluate technologies, products, or methodologies. European Standards are under the responsibility of the European Standardisation Organisations (CEN, CENELEC, ETSI) and can be used to support EU legislation and policies. See http://ec.europa.eu/growth/single-market/european-standards/ index_en.htm (last accessed 1 April 2015).

10. Art. 3 TFEU.

11. See supra nt. 3. 
12. Commission Regulation (EU) No 651/2014 of 17 June 2014 declaring certain categories of aid compatible with the internal market in application of Articles 107 and 108 of the Treaty OJ 2014 L $187 / 1$.

13. Commission Regulation (EC) No 800/2008 of 6 August 2008 declaring certain categories of aid compatible with the common market in application of Articles 87 and 88 of the Treaty General Block Exemption Regulation OJ 2008 L214/3 (amended by Commission Regulation (EU) No 1224/2013 of 29 November 2013 amending Regulation (EC) No 800/2008 as regards its period of application OJ $2013 \mathrm{~L} 320 / 2$ ).

14. Communication from the Commission to the European Parliament, the Council, the European Economic and Social Committee and the Committee of the Regions COM (2012) 209, 8.5.2012 (Communication on State Aid Modernisation).

15. Community framework for State aid for research and development and innovation, OJ $2006 \mathrm{C}$ $323 / 1$.

16. Community guidelines on State aid to promote risk capital investments in small and mediumsized enterprises OJ 2006 C 194/2.

17. Communication from the Commission - Framework for State aid for research and development and innovation OJ 2014 C 198/1.

18. Guidelines on risk finance aid for 2014-2020 OJ 2014 C19/4.

19. Article 107(2) TFEU lists aid that: (a) has a social character and is granted to individual consumers, provided that such aid is granted without discrimination as regards the origin of the products; or (b) makes good the damage caused by natural disasters or exceptional occurrences. It also mentions at letter (c): 'aid granted to the economy of certain areas of the Federal Republic of Germany affected by the division of Germany, in so far as such aid is required in order to compensate for the economic disadvantages caused by that division'. This exemption is of limited practical relevance, and indeed it is now about to be ex lege repealed.

20. Article 107(3) TFEU also mentions (d) aid to promote culture and heritage conservation where such aid does not affect trading conditions and competition in the EU to an extent that is contrary to the common interest, and provides that other categories of aid may be included in a decision of the Council on the proposal of the Commission.

21. Case 730/79, Philip Morris, [1980] ECR 2671.

22. Ex multis Case T-17/03 Schmitz-Gotha Fahrzeugwerke v Commission [2006] ECR II-1139, paragraph 41, and Joined Cases T-267/08 and T-279/08 Région Nord-Pas-de-Calais and Communauté d'agglomération du Douaisis v Commission [2011] ECR II-1999 ; Case T-319/11, ABN Amro Group NV v Commission 8 April 2014 (not yet published).

23. In the specific area of State aid, the Commission is bound by the guidelines and communications that it adopts, in so far as they do not depart from the rules in the Treaty and are accepted by the Member States. See inter alia Joined Cases T-267/08 and T-279/08 Région Nord-Pas-deCalais and Communauté d'agglomération du Douaisis v Commission [2011] ECR II-1999, paragraphs 129 and 132.

24. Risk capital is a broad concept that includes a growing number of types of investment. In the EU legal order, it has been defined as 'equity and quasi-equity financing to companies during their early-growth stages (seed, start-up and expansion phases), including informal investment by business angels, venture capital and alternative stock markets specialized in SMEs including high-growth companies (hereafter referred to as investment vehicles)

25. Commission Staff Working Document Impact Assessment Accompanying the Communication From The Commission 'Framework for state aid for research and development and innovation' SWD (2014) $163 \mathrm{http} / / /$ ec.europa.eu/smart-regulation/impact/ia_carried_out/docs/ia_2014/ swd_2014_0163_en.pdf (last accessed 15 April 2015).

26. Council Regulation (EC) No 994/98 of 7 May 1998 on the application of Articles 92 and 93 EC [now Articles 107 and 108 TFEU respectively] to certain categories of horizontal State aid OJ 1998 L142/1.

27. After 1998, following the Enabling Regulation, the Commission adopted several regulations that provide for certain exemptions. In 2006, the Commission adopted the De minimis Regulation, recently replaced by a new regulation. Measures that fulfil the criteria of the De minimis do not constitute 'state aid' and therefore do not need to be notified to the Commission for approval. See Commission Regulation (EC) No. 1998/2006 of 15 December 2006 on the application of Articles 87 and 88 of the Treaty to de minimis aid, OJ 2006 L 379/5. Commission 
Regulation (EC) No. 1407/2013 of 18 December 2013 on the application of Articles 107 and 108 of the Treaty on the Functioning of the European Union to de minimis aid, OJ $2013 \mathrm{~L}$ $352 / 1$

28. Commission Regulations (EC) 68/2001 OJ 2001 L10/20, 70/2001 OJ 2001 L10/33, 2204/2001 OJ $2001 \mathrm{~L} 337 / 3$, and 1628/2006 OJ 2006 L32/29.

29. Se supra nt. 15. For a general account of the GBER see (Nicolaides 2014).

30. The aid must be transparent in the meaning of the GBER. Recital 20 of the GBER states that 'Transparent aid is aid for which it is possible to calculate precisely the gross grant equivalent ex ante without a need to undertake a risk assessment', and Art. 5 lists categories of aid that are transparent as such (e.g. aid comprised in loans, aid comprised in fiscal measures). Aid granted under the GBER must be under the thresholds laid down in Art. 6. In this regard, it has been widely acknowledged that the ceilings have also been substantially raised as compared with the existing ones, implying that individual aid of larger amounts may be provided without preliminary notification to the Commission. This Regulation exempts only aid that has an incentive effect (Art. 8 GBER).

31. http://ec.europa.eu/competition/state_aid/modernisation/rdi_framework_faq_en.pdf(last accessed 15 April 2015).

32. Para. 12 of the Communication on State aid Modernisation.

33. Defining the relevant market means determining the scope of the competition rules in respect of restrictive practices and abuses of a dominant position, as well as the scope of the merger regulations. The definition is less relevant in the context of State aid, although the notion of market is still necessary to understand the distortive potential of the State intervention.

34. Commission Notice on the definition of relevant market for the purposes of Community competition law OJ 1997 C 372/5.

35. 'Removing Obstacles for the Disabled', Policy Brief of European Commission - DG Justice available at http://ec.europa.eu/justice/citizen/document/files/disabled_en.pdf (last accessed 15 April 2015).

36. See the projects listed in the DISCIT 7.1 deliverable, available at http://discit.eu/publications (last accessed 15 April 2015).

37. Parker, a coordinator of ASTERICS, an EU funded project, explains: 'What I would call the "old" AT-market is dominated by isolated applications and devices, each addressing a specific disability or focusing on a specific ability of the user. This is in principle good, since it means that each device can be brilliantly optimised in its functionality'. See at: http://ec.europa.eu/ digital-agenda/en/news/adaptive-assistive-technologies-people-disabilities (last accessed 15 April 2015).

38. Several studies on the use of AT at home have shown that one-third are abandoned early and lie unused (Scherer and Galvin 1996; Kittel et al. 2002; Scherer 2005) because these devices are not 'consumer friendly', and are not easy to use. An investigation conducted in the US has confirmed that people with disabilities require 'improved design for compatibility, durability, and customizability' and advocates for 'consumer input during market research, product design, and product testing' (Lenker et al. 2013). Interestingly, the participants in this research study articulated concerns about product usability, as well as ideas for new product features: 'Need a screen that doesn't wash out in sunlight'; 'GPS built into chair for location in emergency' ... 'Make cell phone electronics compatible with wheelchair controls' (Lenker et al. 2013).

39. See at http://www.atis4all.eu/default.aspx (last accessed 15 April 2015).

40. A study conducted in Germany with regards to assistive devices for people with ASL shows that, outside of other bureaucratic problems, public financing covers only low prices assistive devices (Henschke 2012).

41. For example, Caccamo and others (2014) observe that, especially in developing (or low income) countries, normal hearing aids are expensive and consequently out of reach to disadvantaged populations. The average price of high quality hearing aids ranges between $\$ 1000$ and $\$ 6000$, therefore limiting the availability and access for many even in developed countries (Caccamo et al. 2014).

42. The iPhone and the android operating system are opposite examples. The same with Windows and even iOS. All were initially inaccessible and have become more accessible.

43. In this article, innovation is conceived, in line with the Community framework for State aid for research and development and innovation, OJ 2006 C 323/1, as 'related to a process connecting knowledge and technology with the exploitation of market opportunities for new or improved 
products, services and business processes compared to those already available on the common market, and encompassing a certain degree of risk'. Product innovation is referred to changes to the products themselves, encompassing the creation of new products or the improvement of existing products.

44. The valley of death describes the point at which a business has a working prototype for a product or service that has not yet been developed enough to earn money through commercial sales (Ford, Koutsky, and Spitwak 2007).

45. Article 114 TFEU confers to EU the power to adopt legislation which has as its object the establishment and functioning of the internal market. Up to now, Article 114 has provided the legal basis for a number of instruments (Waddington 2009, 2013). Declaration No. 22 to the Treaty of Amsterdam stipulates that in drawing up measures under what is now Article 114, 'the institutions of the [EU] shall take account of the needs of persons with a disability.' The rationale behind many accessibility-related legislations adopted under Article 114 TFEU is the elimination of barriers in the Internal market and harmonization of standards of goods and services offered in the EU (Waddington 2009). As the Court of Justice has consistently held that to justify recourse to Article 114 TFEU as legal basis what matters is that the measure adopted on that basis must actually be intended to improve the conditions for the establishment and functioning of the internal market (Case C-376/98, Germany v. Parliament and Council, [2000] ECR I-8419; Case C-380/03 Germany v. European Parliament and Council, [2006] ECR I-11573). Certainly, the Treaty intends to confer on the legislature a discretion in selecting the method of harmonization (minimum or maximum) most appropriate for achieving the desired result (Weatherill 2011).

46. http://ec.europa.eu/smart-regulation/impact/planned_ia/docs/2012_just_025_european_accessibiliy_act_en.pdf (last accessed 30 April 2015).

47. $\operatorname{COM}^{(2008)}$ 426. On the proposal see Waddington (2011b).

48. See infra Section 4. See also Draft Commission Notice on the notion of State aid pursuant to Article 107(1) TFEU, available at http://ec.europa.eu/competition/consultations/2014_state_ aid_notion/draft_guidance_en.pdf (last accessed 30 April 2015).

49. Amongst others, see Veritas project, available http://veritas-project.eu/index.html (last accessed 30 April 2015).

50. Key enabling technologies (KETs) encompass micro-/nanoelectronics, nanotechnology, photonics, advanced materials, industrial biotechnology and advanced manufacturing technologies (which are relevant in developing accessible technology). Communication from the Commission 'A European strategy for Key Enabling Technologies - A bridge to growth and jobs' of 26 June 2012, $\operatorname{COM}(2012) 341$ final.

51. Commission Communication Europe 2020 - A strategy for smart, sustainable and inclusive growth, of 3 October 2010, $\operatorname{COM(2010)~} 2020$ final.

52. Communication from the Commission Europe 2020 - Flagship Initiative Innovation Union, of 6 October 2010, $\operatorname{COM}(2010) 546$ final.

53. Communication from the Commission 'Taking forward the Strategic Implementation Plan of the European Innovation Partnership on Active and Healthy Ageing', of 29 February 2012, COM (2012) 083 final.

54. Communication from the Commission, Proposal for a Decision on the participation of the Union in the Active and Assisted Living Research and Development Programme jointly undertaken by several Member States, of 10. July 2013, COM(2013) 500 final. The AAL JP was created by 20 EU Member States and three associated countries in 2008. The EU decided to match participating countries' support with funding from the 7th Framework Programme for Research and Technological Development (FP7), based on Article 185 TFEU.

55. In this article, we limit ourselves to note that, despite the commitment towards transparency and inclusiveness adopted by the Commission in its communication 'A strategic vision for European Standards' and in the Regulation (EU) No 1025/2012, the capacity of the European standardization process to produce widely accepted and legitimate standards is questioned (Werle and Iversen 2006). As stated in Regulation (EU) No 1025/2012, OJ 2012 L 316/12 SSOs 'are subject to competition law to the extent that they can be considered to be an undertaking or an association of undertakings within the meaning of Articles 101 and 102 TFEU'. With the Guidelines on the application of former Article 81 EC (now, of course, Article 101 TFEU), and then in 2011, with their revised version ('2011 Guidelines'), the Commission provided guidance on standard setting and laid down its general policy toward technological standardization: 
see Communication from the Commission 'Guidelines on the applicability of Article 101 of the Treaty on the Functioning of the European Union to horizontal co-operation agreements', OJ 2011 C 11/1. The '2011 Guidelines' set out possible restrictive effects that standard-setting agreements can give rise to. In addition, they explicitly refer to the creation of barriers to entry and foreclosure concerns, and to the problem of patent hold-up. Whilst accessibility standards are more 'coordinative standards', it is surprising that the Commission did not refer to possible restraints to competition in this context.

56. The Framework also details the boundaries of the Commission's margin of appreciation to approve R\&D aid under Article 107(3)(b) TFEU (i.e. aid for important projects of common European interest). These rules and their application are however out of the scope of this analysis (von Wendland 2012).

57. Para 6 of the 2006 R\&D\&I Framework.

58. R\&D-aid approved under the Framework was granted to different sectors. Several aid measures favoured microelectronics and to a lesser extent ICT-sector. See: Commission Staff Working Paper 'Mid-Term Review of the R\&D\&I Framework' of 10 August 2011.

59. Commission Staff Working Paper 'Mid-Term Review of the R\&D\&I Framework' of 10 August 2011.

60. State aid No N 114/2008 - Germany 'Guidelines on the granting of aid for research, innovation and technology of the Land of North Rhine-Westphalia' OJ 2008 C 256.

61. State aid N 193/2008 - Spain - Aid scheme supporting the realisation of projects of technological development and innovation in the Basque region (programme INNOTEK) OJ 2008 $\mathrm{C} / 253$.

62. State aid N 188/2008 - Spain Spanish national Research, development and innovation scheme OJ $2008 \mathrm{C} / 238$.

63. State aid: Commission approves $€ 400$ million aid to STMicroelectronics for the Nano2017 research programme, Press release IP/14/733 of 25 June 2014.

64. State aid N 406/2009 - Germany (Free State of Bavaria) - Risk Capital Scheme' Clusterfonds Seed GmbH \& Co. KG OJ 2010 C158. See also the letter of the Commission of 12.05.2010, K(2010)2979 final.

65. Aid measure N 756/2007 - Spain - Risk capital measure INVERTEC 2009- 2011 OJ 2009 C108.

66. State aid SA.32520 (2011/N) - Germany Risk Capital Scheme' High-Tech Gründerfonds II, OJ 2012 C70.

67. See http://www.en.high-tech-gruenderfonds.de/2014/03/fresh-capital-for-desino/ (last accessed 30 April 2015).

68. See at http://www.finsmes.com/2013/08/exelonix-raised-funding-high-tech-gruenderfonds. html (last accessed 30 April 2015).

69. State aid N 263/2007 - Germany (Saxony) - Saxon Early Stage Fund (Technology Founder Fund Saxony) OJ 2008 C93.

70. Recital 20 of the GBER stated that 'Transparent aid is aid for which it is possible to calculate precisely the gross grant equivalent ex ante without a need to undertake a risk assessment', and Article 5 lists categories of aid which are transparent as such (e.g. aid comprised in loans, aid comprised in fiscal measures).

71. In the case of investment funds targeting exclusively SMEs located in assisted areas, at least $30 \%$ of the funding was to be provided by private investors.

72. Article 31(4) GBER.

73. SA.32588 Oberösterreichischer Hightechfonds OJ 2011 C110.

74. X77/2010 Fondo Nazionale per l'Innovazione - Capitale di rischio OJ 2010 C75.

75. SA.36232 Förderprogramm "Hochtechnologien für das 21. Jahrhundert OJ 2013 C 213.

76. See http://www.forschungsstiftung.de/index.php/Antragstellung/Foerderrichtlinien.html (last accessed 30 April 2015).

77. The scope of measures that no longer need to be notified to the Commission for prior approval has been widened under the new GBER.

78. State aid: Commission adopts new rules facilitating public support for research, development and innovation; European Commission - IP/14/586 of 21 May 2014.

79. See: Answer of industriAll Europe to the consultation by the Commission on State Aid for Research, Development \& Innovation (R\&D\&I), available http://ec.europa.eu/competition/ consultations/2013_state_aid_rdi/index_en.html (last accessed 15 April 2015) 
80. Article 3(3) TEU.

81. In compliance with Art. 44 UNCRPD, the final decision on the conclusion of the Convention contains a Declaration of competence, specifying which areas of the agreement fall within the competence of the EU and which fall within that of its Member States, or are of shared competence between them.

82. Among the new categories there are also: aid schemes to make good the damage caused by natural disasters, social aid for transport residents of remote regions, aid for broadband infrastructure, aid for culture and heritage conservation, including aid schemes for audio-visual works, aid for sport and multifunctional recreational infrastructures, investment aid for local infrastructure.

\section{References}

Abbott, C. 2007. "Defining Assistive Technologies - A Discussion." Journal of Assistive Technology 1 (1): 6-9.

Abbott, C., D. Brown, L. Evett, and P. Standen. 2014. "Emerging Issues and Current Trends in Assistive Technology Use 2007-2010: Practising, Assisting and Enabling Learning for All." Disability and Rehabilitation: Assistive Technology 9 (6): 453-462.

AEGIS. 2009. Final Deliverable D5.4.1.a Market Analysis Collaborative Project 224348.

Ahtonen, A., and R. Pardo. 2012. "The Accessibility Act - Using the Single Market to Promote Fundamental Rights." European Policy Centre. 12 March 2013. Accessed April 15, 2015. http://www.epc.eu/documents/uploads/pub_3393_the_accessibility_act.pdf

Bauer, S., and L-J. Elsaesser. 2012. "Integrating Medical, Assistive, and Universally Designed Products and Technologies: Assistive Technology Device Classification (ATDC)." Disability and Rehabilitation: Assistive Technology 7 (5): 350-355.

Biondi, A. 2013. "State Aid is Falling Down, Falling Down: An Analysis of the Case Law on the Notion of Aid." Common Market Law Review 50 (6): 1719-1744.

Borg, J., S. Larsson, and P. Östergren. 2011. "The Right to Assistive Technology: For Whom, for What and by Whom?" Disability \& Society 26 (2): 151-67.

Borraz, O. 2007. "Governing Standards: the Rise of Standardization Processes in France and in the EU." Governance: An International Journal of Policy, Administration and Institutions. Accessed April 15, 2015. http://www.diplomatie.gouv.fr/fr/IMG/pdf/standards.pdf

Boyle, R. 2009. "Disability Issues in Public Procurement." In Social and Environmental Policies in EC Procurement Law, edited by S. Arrowsmith and P. Kunzlik, 310-344. Cambridge: Cambridge University Press.

Caccamo, S., A. Voloshchenko, and N. Y. Dankyi. 2014. "The Importance of Creating a Social Business to Produce Low-Cost Hearing Aids." Disability and Rehabilitation: Assistive Technology 9 (5): 368-373.

Charitakis, S. 2013. "An Introduction to the Disability Strategy 2010-2020, with a Focus on Accessibility." Ars Aequi Accessed April 15, 2015. http://www.nuigalway.ie/dream/downloads/ an_introduction_to_the_disability_strategy_20102020_with_a_focus_on_accessibility.pdf

De Cecco, F. 2013. State Aid and the Economic Constitution. Oxford: Hart Publishing.

Deiberova, K., and H. Nyssens. 2009. "The New General Block Exemption Regulation (GBER): What changed?" European State Aid Law Quarterly 27 (1): 27-38.

Deloitte. 2003. Access to Assistive Technology in the European Union-Report for the European Commission. Accessed April 15, 2015. http://www.acessibilidade.net/at/access_AT_EU.pdf.

Ellis, K., and M. Kent. 2011. Disability and New Media. New York: Routledge.

Faeh, A. 2013. "A single European Pharmaceutical Market: Does Maximum Harmonization Enhance Medicinal Product Innovation?" Pharmaceuticals Policy and Law 15 (2013): 7-27.

Ferri, D. 2014. "Is there a "Cultural Dimension" of EU Disability Policy? New Perspectives after the Accession to the UN Convention on the Rights of Persons with Disabilities." In Trasformazioni e crisi della cittadinanza sociale, edited by L. Zagato, D. Costantini, F. Perocco, 241-268. Venice: Venice University Press.

Ferri, D. 2015. “'Subsidising Accessibility'. Using EU State Aid Law and Policy to Foster Development and Production of Accessible Technology." European State Aid Law Quarterly 14 (1): 51-67. 
Ferri, D., and M. Marquis. 2011. "Inroads to Social Inclusion in Europe's Social Market Economy: The Case of State Aid Supporting Employment of Workers with Disabilities." European Journal of Legal Studies 4 (2): 44-73.

Ferri, D., G. A. Giannoumis, and E. O’Sullivan. 2015. "Fostering Accessible Technology and Sculpting an Inclusive Market through Regulation." International Review of Law, Computers \& Technology. doi:10.1080/13600869.2015.1055666

Foley, A., and Ferri, B. 2012. "Technology for People, not Disabilities: Ensuring Access and Inclusion." Journal of Research in Special Educational Needs 12 (4): 192-200.

Ford, G. S., T. Koutsky, and L. J. Spiwak. 2007. "A Valley of Death in the Innovation Sequence: An Economic Investigation." Phoenix Center for Advanced Legal and Economic Public Policy Studies. Accessed April 15, 2015. http://ssrn.com/abstract=1093006 or http://dx.doi.org/10. 2139/ssrn. 1093006

Gassmann, O., and G. Reepmeyer. 2008. "Universal Design - Innovations for All Ages." In The Silver Market Phenomenon: Business Opportunities in an Era of Demographic Change, edited by F. Kohlbacher and C. Herstatt, 125-140. Berlin: Springer/Verlag.

Giannoumis, G. A., and J. Kline. 2014. Deliverable 7.2 (D7.2). Active citizenship through the use of new technologies - the experiences of three generations of persons with disabilities. Accessed April 20, 2015. http://discit.eu/.

Goggin, G., and C. Newell. 2003. Digital Disability: The Social Construction of Disability in New Media. Lanham, MD: Rowman \& Littlefield.

Gramstad, A., S. L. Storli, and T. Hamran. 2014. "Exploring the Meaning of a new Assistive Technology Device for Older Individuals." Disability Rehabilitation and Assistive Technology 9 (6): 493-498.

Halvorsen, R. 2009. "The Accessibility Principle in the UN Convention on the Rights of Persons with Disabilities and Implication for EU Disability Law and Policy." Paper prepared for EFC UNCRPD Implementation Project (unpublished).

Harris, J. 2010. "The Use, Role and Application of Advanced Technology in the Lives of Disabled People in the UK." Disability \& Society 25 (4): 427-439.

Henschke, C. 2012. "Provision and Financing of Assistive Technology Devices in Germany: A Bureaucratic Odyssey? The Case of Myotrophic Lateral Sclerosis and Duchenne Muscular Dystrophy." Health Policy 105 (2-3): 176-84.

Hosking, D. 2013. "Staying the Course: The European Disability Strategy 2010-2020." European Yearbook of Disability Law 4: 73-99.

Kittel, A., A. Di Marco, and H. Stewart. 2002. "Factors Influencing the Decision to Abandon Manual Wheelchairs for Three Individuals with a Spinal Cord Injury." Disability \& Rehabilitation 24 (13): $106-14$.

Lang, J. T. 2014. "EU State Aid Rules - The Need for Substantive Reform." European State Aid Law Quarterly 13 (3): 440-453.

Lawson, A. M. 2010. "Reasonable Accommodation and Accessibility Obligations: Towards a More Unified European Approach?" European Anti-discrimination Law Review 11: 11-21.

Lemley, M. A. 2002. "Intellectual Property Rights and Standard-Setting Organizations." California Law Review 90 (6): 1892-1973.

Lenker, J. A., F. Harris, M. Taugher, and R. O. Smith. 2013. "Consumer Perspectives on Assistive Technology Outcomes." Disability Rehabilitation and Assistive Technology 8 (5): 373-380.

Mabbett, D. 2005. "The Development of Rights-based Social Policy in the European Union: The Example of Disability Rights.” Journal of Common Market Studies 43 (1): 97-120.

Mazzucato, M. 2011. The Entrepreneurial State. London: Demos.

Nicolaides, P. 2014. "An economic assessment of the usability of the new General Block Exemption Regulation for State Aid (Regulation 651/2014)." European Competition Journal 10 (3): $403-417$.

Plender, R. 2004. "Definition of Aid.” In The Law of State Aid in the European Union, edited by A. Biondi, P. Eeckhout, and J. Flynn, 3-40. Oxford: Oxford University Press.

Quingley, C. 2009. European State Aid Law and Policy. Second Edition. Oxford: Hart Publishing.

Ravenberg, B. 2012. "Usability and Abandonment of Assistive Technology." Journal of Assistive Technologies 6 (4): 259-269.

Rossi, L. S. 2012. "Does the Lisbon Treaty Provide a Clearer Separation of Competences between EU and Member States?" Chap. 4. In Law after Lisbon, edited by A. Biondi, P. Eeckhout, and S. Ripley. Oxford: Oxford University Press. doi:10.1093/acprof:oso/9780199644322.003.0004. 
Segura Catalán, M. J., and M. Clayton. 2013. "State Aid Modernisation: Another Reform?" ERA Forum: Scripta Iuris Europaei 14: 21-34.

Scherer, M. J., and J. C. Galvin. 1996. "An Outcomes Perspective of Quality Pathways to the most Appropriate Technology." In Evaluating, Selecting and Using Appropriate Assistive Technology, edited by J. C. Galvin and M. J. Scherer, 1-26. Gaithersberg, MD: Aspen.

Scherer, M. J., J. Jutai, M. Fuhrer, L. Demers, and F. Deruyter. 2007. "A Framework for Modelling the Selection of Assistive Technology Devices (ATDs)." Disability \& Rehabilitation: Assistive Technology 2 (1): 1-8.

Scherer, M. J. 2005. "Assessing the Benefits of Using Assistive Technologies and Other Supports for Thinking, Remembering and Learning." Disability \& Rehabilitation 27 (13): 731-9.

Stack, J., L. Zarate, C. Pastor, N. E. Mathiassen, R. Barberà, H. Knops, and H. Kornsten. 2009. "Analysing and Federating the European Assistive Technology ICT Industry." European Commission Information Society and Media. Accessed April 15, 2015. http://www.oasisproject.eu/docs/ICT_final.pdf.

Ştefan, O. 2013. Soft Law in Court: Competition Law, State Aid and the Court of Justice of the European Union. Alphen aan den Rijn: Kluwer.

Vanderheiden', G. 1998. "Barriers, Incentives and Facilitators for Adoption of Universal Design Practices by Consumer Product Manufacturers." Proceedings of the Human Factors and Ergonomics Society Annual Meeting 42 (6): 584-588.

Vanderheiden', G., and J. Tobias. 2000. 'Universal Design of Consumer Products: Current Industry Practice and Perceptions." Proceedings of the Human Factors and Ergonomics Society Annual Meeting 44 (32): 6-19.

Tridimas, T. 2012. "Competence after Lisbon. The Elusive Search for Bright Lines." In The European Union after the Treaty of Lisbon, edited by D. Ashiagbor, N. Contouris, and I. Lianos, 47-77. Cambridge: Cambridge University Press.

Waddington, L. 2006. From Rome to Nice in a Wheelchair. The Development of a European Disability Policy. Groningen: Europa Law Publishing.

Waddington, L. 2009. "A Disabled Market: Free Movement of Goods and Services in the EU and Disability Accessibility.” European Law Journal 15 (5): 575-598.

Waddington, L. 2011a. "The European Union and the United Nations Convention on the Rights of Persons with Disabilities: A Story of Exclusive and Shared Competences." Maastricht Journal of European and Comparative Law 18 (4): 431-453.

Waddington, L. 2011b. "Future Prospects for EU Equality Law. Lessons to be Learnt from the Proposed Equal Treatment Directive.” European Law Review 36 (2): 163-84.

Waddington, L. 2013. "Comment on Art. 9 - Study on the Implementation by the EU of the UN Convention on the Rights of Persons with Disabilities and the European Disability Strategy 2010-2020." Human European Consultancy for the European Commission (unpublished).

Weatherill, S. 2011. "The Limits of Legislative Harmonization Ten Years after Tobacco Advertising: How the Court's Case Law has become a "Drafting Guide"." German Law Journal 12 (3): 827-864.

Wallach, D., and S. C. Scholz. 2012. "User-Centered Design: Why and How to Put Users First in Software Development." In Software for People, Management for Professionals, edited by A. Maedche, A. Botzenhardt, and L. Neer, 11-38. Berlin: Springer Verlag.

Werle, R., and E. Iversen. 2006. "Promoting Legitimacy in Technical Standardization." Science, Technology \& Innovation Studies 2 (1): 19-39. 